\title{
GLASS AND PERFORATED METAL DOUBLE SKIN FAÇADE PERFORMANCE IN HOT HUMID CLIMATE
}

\author{
Nissa Aulia Ardiani ${ }^{1 *}$, M. Donny Koerniawan ${ }^{2}$ \\ ${ }^{1,2}$ Department of Architecture, Institut Teknologi Bandung, Labtek IX-B Architecture Building \\ *Corresponding author; Email: nissaardiani@gmail.com
}

\begin{abstract}
The construction of a sustainable building in Indonesia has increased in recent years. Middle- to high-rise buildings are encouraged to enhance its performance to reduce energy demands. With maximum temperature $34^{\circ} \mathrm{C}$, most of the buildings in Indonesia utilize mechanical air conditioning to achieve indoor thermal comfort. In this research, the performance of campus building with Double Skin Façade (DSF) in Indonesia would be quantitatively assessed and simulated by utilizing Autodesk Revit and Green Building Studio. In respect to façade material, actual cavity width, inner and outer layer façade type, and also weather condition, these simulations are expected to produce comparison result between four DSF material configurations which are perforated metal, single glazing, double glazing, and triple glazing. From the simulation, the results show that perforated metal DSF could consume 5\%-23.16\% more energy for space cooling compared to building with glass DSF.
\end{abstract}

Keywords: Double skin façade; perforated metal; building performance.

\section{INTRODUCTION}

The emerging of 'Sustainable Building' concept has arisen in the recent years as a result of architects and contractors awareness on the issue of energy problems and environmental damage due to building constructions. Various sustainable active and passive design technologies have been researched and introduced into the design of buildings to minimize the negative impact of building construction and the building existence itself into the environment.

Double skin façade (DSF), as one of the passive design strategies, has been widely used in many buildings in European countries and country in temperate climate region. DSF presumably could improve energy performance during heating and cooling season. Several research such as Haase et al. (2009), Wong et al. (2008), Chan et al. (2009), Mulyadi (2012), and Iyati et al. (2014) also postulate that it is highly possible to apply such technology for the façade in Indonesia which only has cooling season throughout the year. Mulyadi (2012) has conducted DSF research in 2012 with a case study using 23storey office building in Makassar, Indonesia. Different glass specification as inner and outer pane in different cavity distance was simulated utilizing MicroHASP/TES and LCEM-Tool. It was confident that buildings in the tropical climate such as Indonesia could apply naturally ventilated double skin façade to decrease solar heat gain and it was more efficient compared to the single-skin façade or double glazing window system. The result revealed that DSF could minimize more than $50 \%$ heat gain. These studies imply that material configuration is the majority parameter used. Another study by Iyati et al. (2014) found that multi-story DSF type performs better in creating air movement and distributing the air of the façade. The result strengthens the similar research's conclusion that DSF could minimize indoor air temperature and cooling load.

Saelens, Carmeliet and Hens' (2001) study about energy performance assessment of multiple skin facades and discover that it could enhance building performance. However, mechanism control of the system and annual energy simulation are imminent so that layered skin façade could perform maximum in both winter and summer. They also find that the air in the cavity affects energy performance. Besides, the study and analysis of transmissions gains and losses and the enthalpy change of the cavity air are essential for evaluating the energy efficiency of multiple skin façade (Saelens \& Hens, 2001).

Another study by Dewi, Huang, and Nugroho also found that total building energy consumption could decrease proportional to the solar heat gain coefficient (SHGC) and U-Value material. It means that the lower value of SHGC and U-value of the glass, the greater the reduction in energy (Dewi et al., 2014). Besides, recent studies reveal that light transmission factor could affect the energy consumption of the building. This concept was explained by heat transfer process, which higher value of light transmission will influence heat from UV light that enters the room and in the end, it could affect the 
energy demands. This theory will be used in the research as a background theory for simulating various kind of DSF.

As the façade technologies developed, DSF utilizes a various type of material. Metal façade is used as shading devices and give appealing looks of the building while providing durability and resistance. Nonetheless, there is no advance and particular study about using perforated sheet metal for DSF under hot and humid climate region. High precipitation, humidity, and solar radiation make buildings in such location require a durable material which suitable with climate and available resources.

Blanco et al. (2014) studied perforated sheet metal material in the building under Spain's weather condition. Theoretical model and experiment in the material were carried to examine the behaviour of perforated sheet metal DSF classified by colour, metal material type, and perforation rate. This study was supposed to be the strongest literature explained about perforated metal DSF. However, the simulation result by Energyplus also has not been published yet so that the simulation methods could not be reviewed. Therefore, the research will not follow methods used by Blanco because it utilized the numerical validation that is not feasible to conduct within the time frame.

Nevertheless, at the time this paper was written, there are no previous studies that simulate perforated metal DSF using Autodesk Revit and Green Building Studio. For validation of this research, Green Building Studio is built and validated with DOE-2.2 simulation engine and also were evaluated and met the criteria of ANSI/ASHRAE Standard 140. In this study, how the perforated sheet metal DSF works compared to glass DSF regarding performance and sustainability will be examined. It is expected that application of perforated sheet metal create not only natural air movement but also provide natural daylight of the building.

\section{METHODOLOGY}

Inductive approach is used in this study because the answer of research question still uncertain and it might be different from the hypothesis that has been described. This research will use a Quantitative method by utilizing software to build a model under the real condition of the building as well as climate and weather condition.

This study will use UMN Campus located in Tangerang, Indonesia. In precise, the latitude is $6.2567^{\circ}$ South and longitude $106.6182^{\circ}$ East (Maps, 2015), which considered as a part of tropical or hot and humid climate region. This archipelago country has two monsoonal wet and dry seasons with average rainfall between 1,780-6,100 millimeters per year. Weather in this country may immensely affect the physical building through active and passive design architecture. In average, the temperature of Tangerang is between $19^{\circ} \mathrm{C}-34^{\circ} \mathrm{C}$. The highest relative humidity is found to be in the morning in January that reach more than $80 \%$, while the lowest is between September and October in the afternoon with approximately $37 \%$. The annual average wind speed is at between $12-18 \mathrm{~km} / \mathrm{h}$ in West-Southwest direction and precipitation is markedly high from October to April.

Completed in 2012, UMN Campus building using DSF with metal perforated aluminium for the outer layer to let daily sunlight penetrates the building and $3 \mathrm{~mm}$ clear glass for the inner layer. This 13 floors building has several facilities including 125 classrooms, theatre, computer rooms, TV and radio studio, and photo studio with total area $30000 \mathrm{~m}^{2}$. The building also won ASEAN Energy Award 2014 for Energy Efficient Building category Tropical Building in Vientiane, Laos and awarded as 'Most Energy Efficient New Building' in the 2013 National Energy Efficiency Awards.
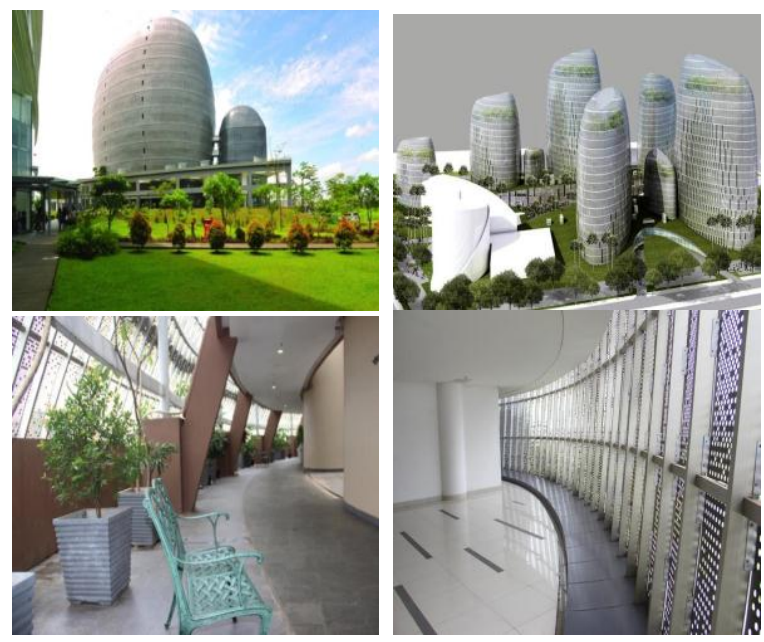

Fig. 1. Several Pictures of UMN Campus Building, Indonesia (Source: http://library.umn.ac.id/jurnal/; http:// buildingindonesia.co.id/?p=191; http://green.kompasiana.com/)

As mentioned earlier, this research has been conducted by using two software: Autodesk Revit for the modelling and Autodesk Green Building Studio for energy performance analysis. There are two models developed for the simulation, simplified model of one particular floor and the whole UMN building. These models were then simulated in different double skin façade's material properties, with metal perforated and glass. Since the building data is collected directly from the architect designer and company, who construct UMN Campus and weather 
data collected by nearest weather station of Autodesk Climate Server, reliability and validity of this research could be assured.

The process of this research was divided into 4 stages, firstly was determine the precise location and find the nearest weather station directly in Autodesk Revit. Secondly, CAD drawing of UMN building was converted into a 3D model and applied the material in Autodesk Revit. The third stage was simulating the building model in the Autodesk Green Building Studio in different material properties. This software has an extension in Autodesk Revit so that the simulation could be accessed and controlled directly from Revit software. Lastly, the simulation result was derived, compared, and analysed.

One particular floor in UMN building was simulated. Therefore, the third floor was chosen to observe the Double Skin Façade materials effect into the building. By simulating the one-floor model, the parameters that involved in the calculation would become more specific because other building elements have been simplified. Building elements such as the void in stairs, lift, and an auditorium, were omitted to eliminate relations with the upstairs and downstairs floor.

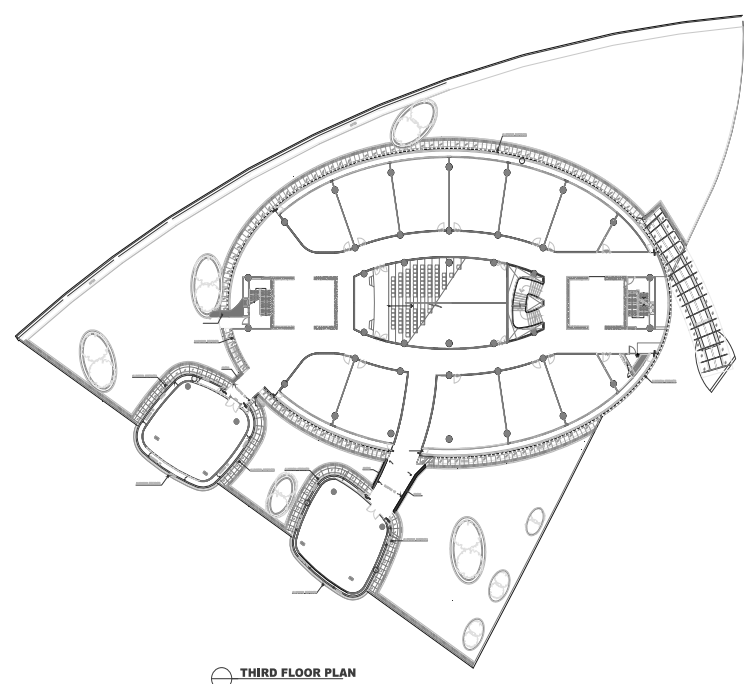

Fig. 2. CAD drawing of third floor's UMN Campus building. (Source: Total Bangun Persada drawing documentation)

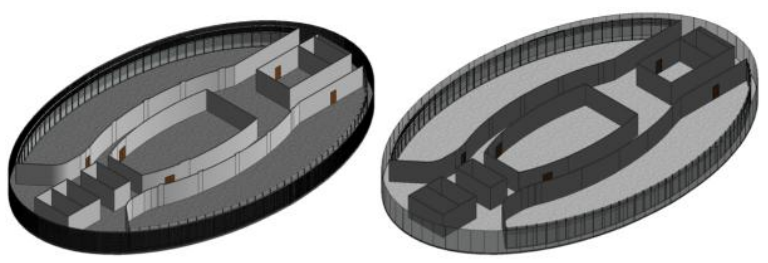

Fig. 3. Left: Perforated Metal DSF model; Right: Glass DSF model (Source: Personal documentation)

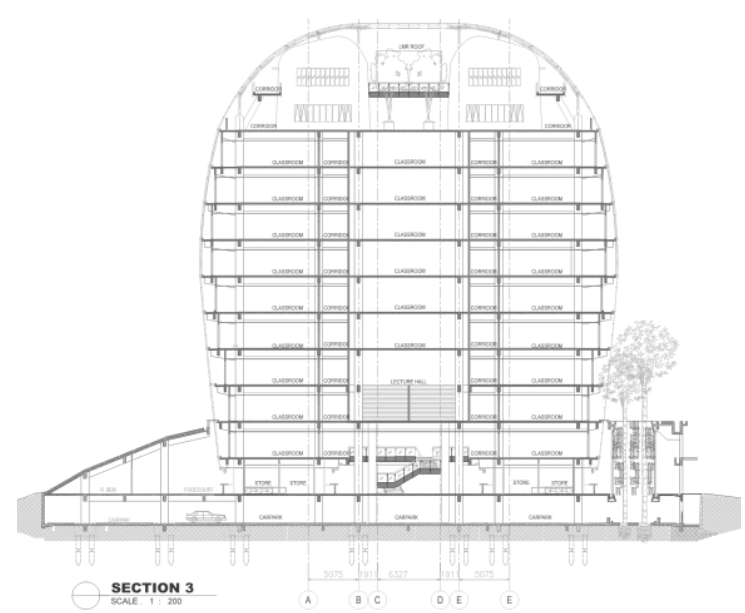

Fig. 4. Building Section showing Cavity between Facades. (Source: Total Bangun Persada drawing documentation)

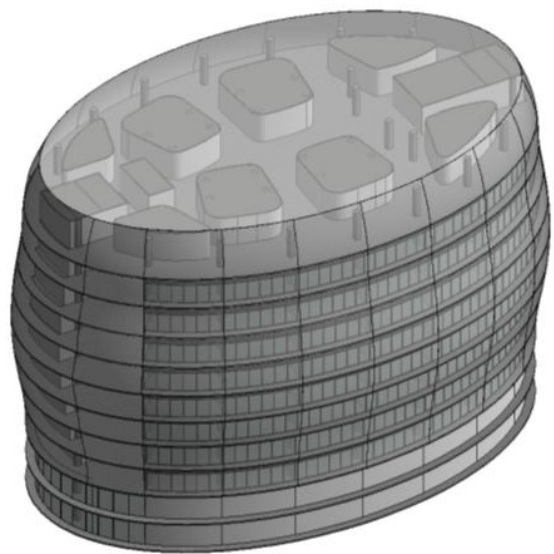

Fig. 5. The Whole UMN Building Model (Source: Personal documentation)

The aim of modelling the entire UMN building in the software is to simulate the total energy consumption affected by the DSF material differences. The figure below is the CAD drawing of UMN building section. It could be seen that the cavity between outer pane and the inner pane in each floor are adjusted to the floor slabs that creates an oval shape of the building. However, some element of the model were changed or removed. It is because the limitation of the software is somehow could not simulate the complicated model. In the real building, basement and the ground floor is sunken from the site level as seen in the figure below

It has been mentioned before that there are two primary materials applied in this simulation, which is perforated metal and glass. However, currently, there is no perforated metal material library in Autodesk Revit or any other software. The perforated metal material was manually created in the model by using Autodesk Revit with "family" features. This "family" was panel component of curtain wall that will be implemented to the building model as double skin façade. 
Table 1. Material Properties for Double Skin Façade

\begin{tabular}{lccccc}
\hline \multirow{2}{*}{ Name } & Width & $\begin{array}{c}\text { Visual Light } \\
\text { Transmittance }\end{array}$ & $\begin{array}{c}\text { Solar Heat Gain } \\
\text { Coefficient }\end{array}$ & $\begin{array}{c}\text { Thermal } \\
\text { Resistance }\end{array}$ & $\begin{array}{c}\text { Heat Transfer } \\
\text { Coefficient }\end{array}$ \\
\cline { 2 - 6 } & $(\mathrm{mm})$ & (Tvis) & (SHGC) & $(\mathrm{R})$ & $(\mathrm{U})$ \\
\hline $\begin{array}{l}\text { Perforated metal (perforation rate } \\
50 \%)\end{array}$ & $2 \mathrm{~mm}$ & 0.00 & 0.00 & $0.2701 \mathrm{~m}^{2} \mathrm{~K} / \mathrm{W}$ & $3.7021 \mathrm{~W} / \mathrm{m}^{2} \mathrm{~K}$ \\
Single glass & & & & & \\
Double glazing & $3 \mathrm{~mm}$ & 0.9 & 0.86 & $0.1491 \mathrm{~W} / \mathrm{m}^{2} \mathrm{~K}$ & $6.7069 \mathrm{~W} / \mathrm{m}^{2} \mathrm{~K}$ \\
$\begin{array}{l}\text { Double glazing } \\
\text { Triple Glazing }\end{array}$ & $3 \mathrm{~mm}$ each & 0.72 & 0.41 & $0.5032 \mathrm{~m}^{2} \mathrm{~K} / \mathrm{W}$ & $1.9873 \mathrm{~W} / \mathrm{m}^{2} \mathrm{~K}$ \\
Source & 6mm each & 0.7 & 0.37 & $0.5032 \mathrm{~W} / \mathrm{m}^{2} \mathrm{~K}$ & $1.9873 \mathrm{~W} / \mathrm{m}^{2} \mathrm{~K}$ \\
\hline
\end{tabular}

Source: Data derived from Autodesk Revit material gallery
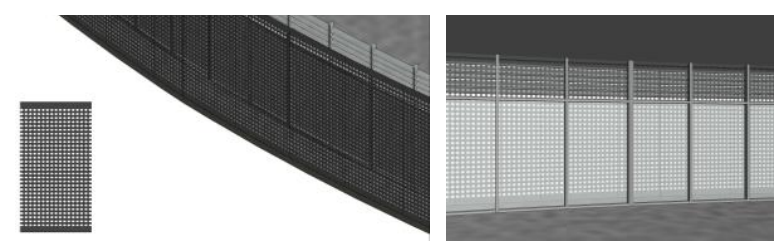

Fig. 6. Manually created perforated double skin facade panel in Autodesk Revit software

Table 2. Configuration of Outer Pane (DSF) and Inner Pane (curtain wall)

\begin{tabular}{ccc}
\hline Code & Outer pane & Inner pane \\
\hline P-01 & Perforated metal & Single glazing \\
G-01 & Single glazing & Single glazing \\
G-02 & Double glazing & Single glazing \\
G-03 & Triple glazing & Single glazing \\
\hline
\end{tabular}

Perforation rate of perforated metal is $50 \%$, and in this model, the hole diameter is 40 millimeters. Furthermore, visual light transmittance, solar heat gain coefficient, thermal resistance, and heat transfer coefficient of the materials above were derived from Autodesk Revit material library as can be seen in Table 1.

The simulation on the one-floor model was divided into four configurations of outer pane and inner pane material as described in the following table. Code P-01 was the arrangement of the actual building while the other codes are the configuration of the different type of glazing.

Several assumptions have been made for this study to determine the vague building elements or factors that could not be obtained from data collection and survey. Some of which are following: Structural column, interior wall, floor slab, ceiling, and door were using a common basic material in Indonesia construction.

The longest façade were facing South and North.

1. There was no basement and floor with double skin façade is started from the third level.

2. The walls between classrooms were omitted with an assumption the amount of daylight enter the interior would be the same with or without separating wall (ignore the daylight reflection in the wall).
3. Because of Autodesk Green Building Studio could not calculate natural ventilation in the energy simulation, in the model there was no inlet in the Double Skin Façade (outer skin).

4. HVAC system used in the simulation was Central VAV, HW Heat, Chiller 5.96 COP, Boilers 84.5\% efficiency (default setting in Autodesk Revit)

\section{RESULTS AND DISCUSSION}

The simulation was performed in Autodesk Cloud, and the result can be obtained in Autodesk Green Building Studio website. The charts below show that the various material configurations in onefloor model give different results in annual electric end-use. Nonetheless, cooling energy needs the biggest space compared to the rest as it is shown in the figures below. It justifies the statement that the buildings in tropical climate do spend the majority of energy in reducing the interior temperature to meet the indoor thermal comfort. The analysis comparison result will be presented for further in the next section.
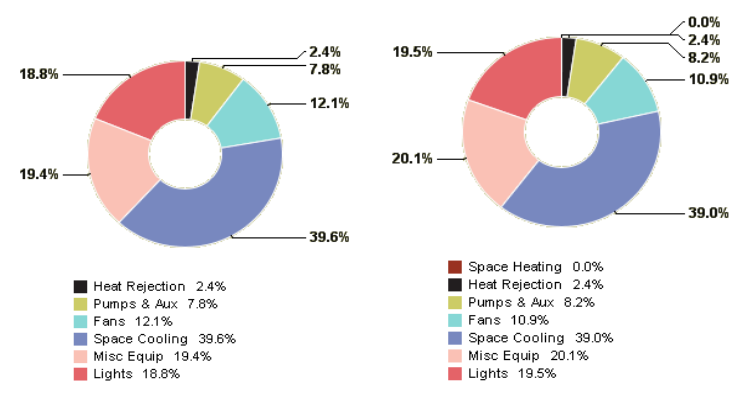

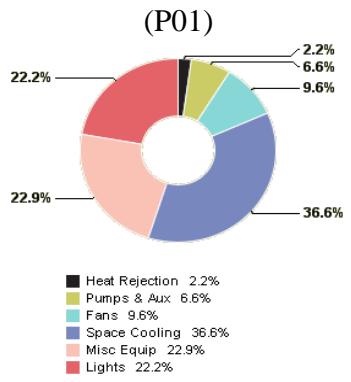

(G02)

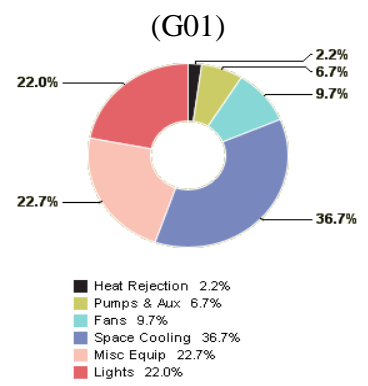

(G03)
Fig. 7. Annual Electric End Use one floor model with different material Double Skin Façade (Source: Autodesk Green Building Studio result) 
Figure 8 below shows the one-floor model energy consumption in which the measurement is based on monthly electricity cooling-loads. Generally, concerning cooling demands, along with other material models, perforated metal DSF material requires the highest demand. Meanwhile, triple glazing DSF model is the least compared to the others. Based on Autodesk Green Building Studio simulation result, the peak of cooling demands is on March by 11498 $\mathrm{kWh}, 10825 \mathrm{kWh}, 9515 \mathrm{kWh}$, and $9198 \mathrm{kWh}$ for perforated metal DSF, single glazing DSF, double glazing DSF, and triple glazing DSF respectively. In contrast, minimum cooling loads are required on September by $8854 \mathrm{kWh}, 8311 \mathrm{kWh}, 7063 \mathrm{kWh}$, and $6752 \mathrm{kWh}$ for perforated metal DSF, Single glazing DSF, double glazing DSF, and triple glazing DSF respectively.

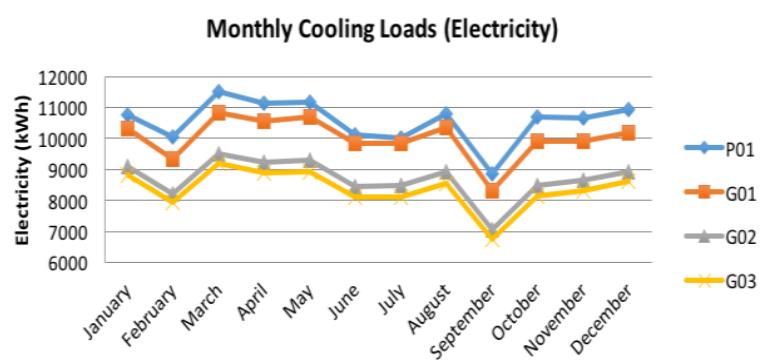

Fig. 8. Comparison of Monthly Cooling Loads (electricity) in one-floor model with different material configurations (Source: Personal documentation)

From these materials arrangement, it can be seen in figure 9 that triple glazing (Low-E/Low-E/Clear) as the lowest U-value material could perform better than perforated metal, single glazing, and double-glazing DSF. The result supported the theory by Dewi, 2014 et all in the literature review that stated material with the low value of SHGC and U-value, could decrease the energy (Dewi et al., 2014). The total annual electricity requisite for cooling the space with triple glazing DSF was $100374 \mathrm{kWh}$ while the perforated metal model was $126674 \mathrm{kWh}$ as seen in figure 9 below.

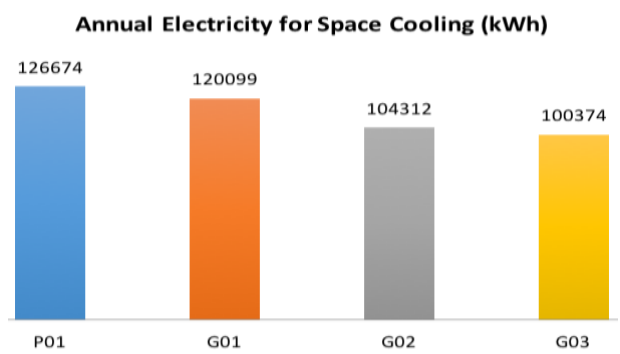

Fig. 9. Comparison of Annual Electricity for Space Cooling in One-Floor Model with Different Material Configurations (Source: Personal documentation)
Figure 10 below shows how much the amount of cooling energy (in Mega Joules) needed per floor area for each project in a year. It can be seen that perforated metal DSF uses more energy compared to other material configurations. On the same floor area but with different DSF material, perforated metal, single glazing DSF, double glazing, and triple glazing need of $277.82 \mathrm{MJ} / \mathrm{m}^{2}, 263.37 \mathrm{MJ} / \mathrm{m}^{2}, 288.75 \mathrm{MJ} / \mathrm{m}^{2}$, and $206^{2} \mathrm{MJ} / \mathrm{m}^{2}$ respectively.

\section{Electricity Energy Use Intensity (EUI) for Space Cooling $\left(\mathrm{MJ} / \mathrm{m}^{2}\right)$}

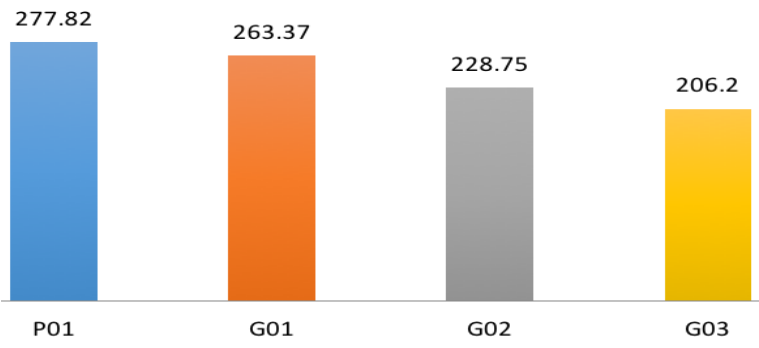

Fig. 10. Comparison of Energy Use Intensity (EUI) for Space Cooling in one-floor Model with Different Material Configurations

Source: Personal documentation

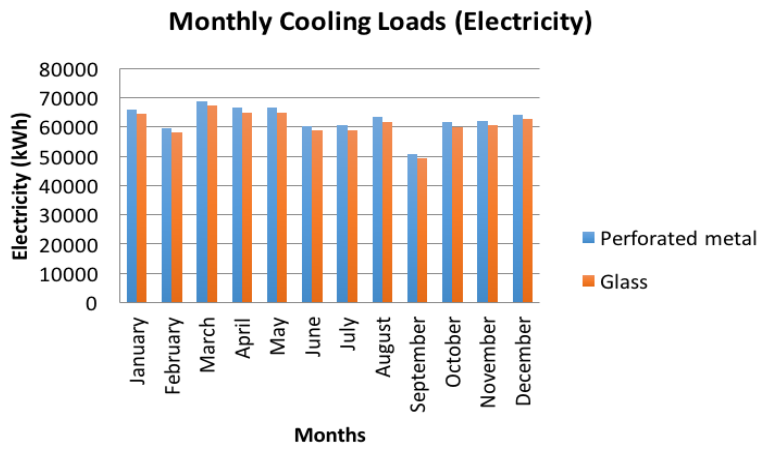

Fig. 11. Monthly Electricity of Cooling Loads in whole Building Model (Source: Personal documentation)

The overall result of simulation for the entire building model reports that perforated metal DSF model has a higher amount of energy consumption and higher cost compared to glass DSF. The figure 11 above shows that the trend of monthly cooling loads and cost was similar with the one-floor model. The energy performance simulation result from one building model and whole building model could use as the reference for examining material performance in the early stage.

\section{CONCLUSION}

In general, result from simulation regarding the aim and objectives of this study could be derived. However, some distinct results also generated from 
the simulation in the whole building model. To concise, the simulation study and analysis of building with perforated metal and glass double skin façade material, the summary, conclusion, and recommenddation for future studies will be described in this chapter. With the aim, objectives, it could be concluded that the building with perforated metal double skin façade could consume 5\% - 23.16\% more energy for space cooling than the building with glass DSF. It happens because there is no natural ventilation system for the building. It is also proportional to the energy cost. On the other hand, triple glazing - double skin façade could save annual cost for cooling energy \$2089.31 less than building with perforated metal double skin façade.

This result of energy performance simulation by Autodesk Green Building Studio support the theory that thermal properties of the material with lower solar heat gain coefficient (SHGC) could decrease the cooling loads in the cooling period. It can be seen that triple glazing has the lowest solar heat gain coefficient among the other material configurations and results from this research proved it. Other than that, because of triple glazing have a high value of thermal resistance and low value of heat transfer coefficient; it also makes it as the excellent material for insulation.

Further research on the same topic by investigating the thermal behaviour of the DSF material configurations would be beneficial. If the perforated metal already in the software's material library, it can be very helpful, so that the research or study on this topic could be more reliable. When simulating the thermal performance, natural ventilation should also be included to examine whether the perforated metal material could perform better together with the cross system ventilation in the building. Therefore, natural ventilation system might be suitable for the perforated metal material where winds could freely get in and out of the building. Furthermore, thermal and wind behaviour in the cavity between outer panel and inner panel could be investigated to study the further effect of perforated metal double skin façade into building compared to glass double skin façade which has been widely considered.

\section{ACKNOWLEDGEMENT}

I would like to thanks to Indonesian Endowment Fund (LPDP) who give me the scholarship and financial support during my master study at The University of Nottingham, UK. I also want to give my gratitude to the supervisors in the process of this research, Dr. Edward Cooper and Dr. Eng M. Donny Koerniawan. Last but not least, Architecture Department of Institut Teknologi Bandung (ITB) where I got my undergraduate degree and work for now.

\section{REFERENCES}

Blanco, J. M., Arriaga, P., Roji, E. \& Cuadro, J. (2014). Investigating the thermal behavior of double-skin perforated sheet façades: Part A: Model characterization and validation procedure. Building and Environment, 82, pp.50-62.

Chan, A. L. S., Chow, T. T., Fong, K. F. \& Lin, Z. (2009). Investigation on the energy performance of double skin façade in Hong Kong. Energy and Buildings, 41, pp.1135-1142.

Dewi, C. P., Huang, R.-Y. \& Nugroho, A. M. (2014). Strategi Double Skin Fasade pada Bangunan Kampus National Central University dalam Menurunkan Kebutuhan Energi Pendinginan. Jurnal Ruas, 11, pp. 51-59.

Haase, M., Marques da Silva, F. \& Amato, A. (2009). Simulation of ventilated facades in hot and humid climates. Energy and Buildings, 41, pp.361-373.

Iyati, W., Wonorahardjo, S. \& Indraprastha, A. (2014). Natural airflow performance of doubleskin facade types. Architecture and Built Environment, pp.41.

Maps, G. 2015. Universitas Multimedia Nusantara.

Mulyadi, R. (2012). Study on naturally ventilated double-skin facade in hot and humid climate. Doctor of Engineering, Nagoya University.

Saelens, D. \& Hens, H. (2001). Experimental evaluation of airflow in naturally ventilated active envelopes. Journal of Building Physics, 25, pp.101-127.

Wong, P. C., Prasad, D. \& Behnia, M. (2008). A new type of double-skin façade configuration for the hot and humid climate. Energy and Buildings, 40, pp.1941-1945.

https://gbs.autodesk.com/GBS/ 